Univerzitet u Beogradu
Poljoprivredni fakultet
Institut za poljoprivrednu tehniku
Naučni časopis
POLJOPRIVREDNA TEHNIKA
Godina XLIV
Broj 3, 2019.
Strane: $44-58$
Faculty of Agriculture

UDK: 631.3.

\title{
AGRICULTURAL FIELD MACHINERY SELECTION AND UTILIZATION FOR IMPROVED FARM OPERATIONS IN SOUTH-EAST NIGERIA: A REVIEW
}

\author{
Okechukwu Oduma ${ }^{1}$, Sylvester I. Oluka ${ }^{2}$, Nnaemeka R. Nwakuba ${ }^{1 *}$, \\ and Dilibe I. Ntunde ${ }^{2}$ \\ ${ }^{1}$ Department of Agricultural and Bioresources Engineering, \\ Michael Okpara University of Agriculture, Umudike, Nigeria. \\ ${ }^{2}$ Department of Agricultural and Bioresources Engineering, \\ Enugu State University of Science and Technology, Enugu, Nigeria
}

\begin{abstract}
A review of agricultural field machinery selection and utilization for improved farm operations in South-east Nigeria was conducted. Proper selection and utilization of machinery effortlessly would boost up and optimize farm production by minimizing unnecessary breakdown/failure, energy and power losses and mismatching of implements to prime movers. These could only be achieved with the aid of performance data of the various field machinery. The review indicated that average performance efficiency of disc plough in South-East Nigeria was $87.11 \%$, whereas harrow, ridger, rotovator and planter were $86.32 \%, 86.78 \%, 87.14 \%$ and $86.81 \%$, respectively. The review further revealed that most studies were focused on a few soil types with few field implements. It was also observed from the review that data obtained for performance of various field machinery vary from one region to another and from one soil type to the other due to variation in ecological soil conditions. Most studies reviewed did not consider the energy and power requirements of the machinery in operation. More so, variations in agro-ecological soil types and conditions require studies of different agricultural zones/areas to obtain data of the performance characteristics of agricultural field machinery that would guide farmers and users of agricultural field machinery in the selection of appropriate machines for their agricultural field operations in order to increase their production at reduced costs. Field test results of some farm machineries were also presented. Prospects for future work were suggested.
\end{abstract}

Keywords: Field machinery, performance, selection, utilization, South-east Nigeria.

\footnotetext{
* Correspond Author. E-mail address: nrnwakuba@gmail.com
} 


\section{INTRODUCTION}

Agricultural field machinery refer to those machines/implements basically used in the farm for field operations such as land clearing machines; tillage or seed bed preparation machines; seed planting machines, fertilizer applicators, mechanical weeding machines; sprayers for weed and pest controls; harvesting machines and transporting machines [1]. These machines are powered by prime movers (tractor) and are used in the farm for agricultural field operations. Most of these machines are fully mounted/ hitched, semi-mounted, self-propelled or trailed implements. Modern agricultural operation demands the application of these field machinery and implements in different farm operations from field clearing to harvesting operation [2].

There are many land areas available in different areas of the world today, but not all the lands are suitable for crop production, and in order to make them economically feasible for agricultural production, different mechanical tillage operations will be conducted. The most important operations required include: adequate seed bed preparation for seed planting, germination, proper growth of the crop, mechanical weed control or application of herbicides/pesticides, fertilizer application, harvesting and conveying of farm produce to the final/designed destination [3]. The authors further noted that farm machineries are designed to carry out these agricultural operations at specified time and cost. But when these designed purposes are not realized, it shows that such machinery/equipment and their power units are doubtful.

Yahanna and Ifem [4] posits that an experienced farmer endeavors to utilize in full capacity agricultural mechanisms such as farm machinery, pest and weed control measures, seed planting, fertilizer and water applications, energy supply, livestock feeds etc., in order to optimize production at reduced cost. They added that farm machinery are devices that enable other inputs achieve the needed results and can be believed that farm machinery and the system of operation generally make up the field of farm mechanization. Most of the increased crop production which was recorded over the years in agriculture is attributed to principally the high utilization of appropriate machines and implements [5]. Oduma et al. [6] noted that farmers are prudent and much concerned about the quality and quantity of the performances of their machines during operation to ensure that they are able to recover the expenses incurred either in hiring/purchasing or maintenance of such machinery. Sale et al. [7] maintained that agricultural operations are time dependent, in order words, they are timely and cost intensive. Accessing the field performance of farm machines is therefore considered economically wise for better selection, optimization and proper farm scheduling.

Oluka [8] also noted that it is important to know the various indicators associated with the cost of owning and operating farm tractors to enable a farmer know if he/she is making profit or loss in the farm business by using tractor and implements (such as plough, harrow, ridger, rotovator, planter etc.). Withney [9] asserts that effective machinery utilization and management demand knowledge of the performance data on the efficiencies of the available machines to be able to meet up with a given work schedule and to establish a balanced system of mechanization which will match the capacities of different equipment. There are considerable differences in operating conditions, such as land topography, hardness/stoniness of the soil, surface roughness, and traficability of the soil; machines/implements may be assessed on a short time in productive operation - equivalent to working speed trials or evaluated over-time taking into account the delays encountered during operation [4]. Braid and Gwarzo [10] suggested that machine performance should be examined if an accurate knowledge of it is to be secured. 
The performances of farm machinery are conversely influenced by different factors. These factors include the power units, machine/implements condition, nature of field, crop type, weather condition, soil type/condition and system of management.

Onwualu et al. [2] stipulated that it is important to ascertain how a machine/implement carries out a given farm operation and the rate with which it performs it. This information is necessary because it promotes machinery management and utilization and other economic aspects in addition to timeliness of farm operations. According to them timeliness is the capacity to carry out an activity in a period that the quality and quantity of the output are broadly and effortlessly optimized. Capacitive performance is an indicator that determines how a given machine/implement completes a work schedule within the limit of time [7]. Performance of any farm machine suggests solutions to the question, "will the machine handle and complete a given field operation within the allowable constraints of time considering the variations in field conditions"? Or will it be a bad investment not withstanding its cost? Tractor and its hitched implements supposed to perform tasks adequately in seed planting, mechanical weeding, application of fertilizers, pest/weed controls and harvesting of crops at reduced damage of crops; also prepare suitable seed bed while maintaining the moisture content of the soil; enhance good soil aeration and the required environmental condition for crop growth/development and protect the soil against erosion and nutrient/sediment losses etc.

Furthermore, energy is another significant indicator in farm operations. According to Updhyaya et al. [11], it plays an important role in different land tillage operations, seed planting operation, application of fertilizers, pest/weed controls harvesting of crops etc.,

Therefore, fuel cost of tillage and/or agricultural productivities should be effortlessly kept at a reduced level to ensure that no amount of operation will lead to high operation cost per hour or keep the cost at a prohibitive level. Thus, machinery operation should be simple and cheap, consistent and low in fuel consumption [12].

Bukhari and Baloch [13] observed that operation speed, implement effective working width and cutting depth, soil type/conditions and operator's skill influence fuel (energy) consumption rate. It therefore means that size of implement and speed of operation should be matched to machine size to improve the field capacitive performance of the machine [14]. The performance efficiencies of farm machinery can generally be evaluated by the rate at which they carry out their field operations and the quality and quantity of production. Gbadamosi and Magaji [15] stated that machine field capacity is the rate at which the machine can cover a given field operation within the limit of time. Kaul et al. [16] noted that effective capacity is evaluated by the rate of working of implement measured in hectares per hour, and that the indicators involved are the implement operation width and the working speed with the allowance for time loss, in turning at the end of the field, adjustment and servicing of the machines. The efficiency of machines/implements indicates how good the machine can perform its functions. According to [6], an experienced farmer is usually conscious of the effective and efficient operation of his/her farm machinery because poor operation or improper utilization of the equipment may lead to great operating loss and minimizes production or result in total loss of money/productivity.

Anazodo et al. [17] noted that, due to some differences in the agro-ecological soil conditions, performance data of the field capacities of machines under varying soil type/conditions is very essential for machinery selection; the performance data are the essential parameters for assessing the performances of farm machinery. But regrettably this information are not provided to farmers or farm managers in Nigeria by the producers of the machines to guide the farmers in assessing and making proper selection of the machine/implement prior to purchase. 
However, huge amount of money is invested by farmers annually in purchasing/hiring, operation, maintenance and management of agricultural field machinery. Most of these machines breakdown/fail unnecessarily during operation, in addition to high energy and power losses incurred in operation due to improper selection of machinery that suit the soil condition and/or mismatching of the implements with the prime mover. Knowledge of the performance characteristics and power unit of the machines will effortlessly ameliorate the plight of farmers, and help them to improve and optimize their production when they make better selection of machines that will match their soil type/conditions. The objective of this work is to review the selection and utilization of agricultural field machinery in South- East Nigeria for improved farm operations.

\section{POTENTIAL IMPACT OF MACHINERY PERFORMANCE AND SELECTION}

Today's competitive agricultural market demands better utilization/ management of resources and minimization of operating costs so as to optimize production and increase profits. One of the major costs of any agricultural production system is machinery cost. Increasing the performance efficiency of farm machinery may lead to a serious cost reduction. Farmers like other business ventures strive to cover up their expenditures in addition to the cost of the machinery. This is why [4] noted that an intelligent and well experienced farmer tries to make proper use of farm inputs (seeds, fertilizers, herbicides or insecticides, irrigation water and farm equipment) so as to reduce cost. In Nigeria, farm mechanization technology has continually been import - oriented. Agricultural machines and equipment are imported from different countries into Nigeria to aid the different farm mechanization decisions of the government [18]. Presently, the cost of importation of agricultural machinery has been sky rocketed due to the devaluation of the local currency and to operate within such a bad economic condition, machinery managers, owners and/or users must be careful in selecting and purchasing new machinery. It is therefore necessary that the users should know how a machine performs a given task and the ease and/or rate with which it does the work without failure or breakdown and at minimal wastage of energy and operation time.

According to Grisso et al. [19], field efficiency is an essential factor for assessing the field capacity and for adopting necessary management policies. The authors maintained that machine capacity is used to ascertain how machine will carry out its functions and that it ensures timeliness of operation. Von Bargen et al. [20] maintained that field efficiency implies completing a given field task at minimum waste of time, energy and other farm resources. According to them, timeliness describes the actual time the field operation should take, initiate turning and other non- productive time. Field efficiency explains the relative magnitude or proportion of the total productivity of any given machine/implement based on the nature of the farm and the maximum production of the machine; and depends on the factors such as: theoretical field capacity of machine/implement, machine maneuverability, machine repair in the field, pattern of the field, shape of field, size of farm land, operator's experience/skills, crop moisture content, nature of crop yield and soil type/conditions [21]. Generally, field efficiency takes into account time losses and the ability to use the full width of machines/implement. Effective field capacity is the rate of field coverage or crop handled in a particular period based on total field time. Theoretical field capacity on the other hand is the actual rate of performance achieved when a machine carries out its function $100 \%$ of the time at a particular working speed applying $100 \%$ of its working width. 
It represents the time taken by a machine to operate in the field from the commencement of the field operation until the end of the work. Table 1 shows the ranges of field efficiency at different speed range for some of the farm machines as observed by [1].

Table 1. Range of typical field efficiencies and implement operating speeds*.

\begin{tabular}{|c|c|c|c|}
\hline $\begin{array}{c}\text { Field } \\
\text { Operation }\end{array}$ & Equipment & $\begin{array}{c}\text { Field } \\
\text { efficiencies, } \\
\%\end{array}$ & $\begin{array}{c}\text { Operating } \\
\text { speeds, } \\
\text { kmh }^{-1}\end{array}$ \\
\hline \multirow{4}{*}{ Tillage } & Moldboard plow & $88-74$ & $5-9$ \\
\hline & Disk harrow & $90-77$ & $6-10$ \\
\hline & Spring-tooth or spike-tooth harrow & $83-65$ & $6-12$ \\
\hline & Field cultivator, Chisel plow & $90-75$ & $6-9$ \\
\hline \multirow{2}{*}{ Cultivation } & Row crop cultivator & $90-68$ & $3-9$ \\
\hline & Rotary hoe & $88-80$ & $9-20$ \\
\hline \multirow[t]{7}{*}{ Seeding } & Row planter with fertilizer & $78-55$ & $7-10$ \\
\hline & Grain drill with fertilizer & $80-65$ & $5-10$ \\
\hline & Broadcaster & $70-65$ & $7-10$ \\
\hline & Potato planter & $80-55$ & $9-12$ \\
\hline & Mower-conditioner & $95-80$ & $5-9$ \\
\hline & Rake & $89-62$ & $6-9$ \\
\hline & Baler, rectangular & $80-65$ & $5-10$ \\
\hline \multirow[t]{7}{*}{ Harvesting } & Baler, round & $50-40$ & $5-19$ \\
\hline & Forage harvester, shear bar & $76-50$ & $6-10$ \\
\hline & Combine & $90-63$ & $3-8$ \\
\hline & Corn picker & $70-55$ & $3-6$ \\
\hline & Windrower, swather & $85-75$ & $6-10$ \\
\hline & Potato harvester & $90-50$ & $3-6$ \\
\hline & Cotton, spindle picker & $90-65$ & $3-5$ \\
\hline \multirow{4}{*}{ Miscellaneous } & Sprayer & & \\
\hline & Anhydrous ammonia applicator & $65-55$ & $6-9$ \\
\hline & Rotary stalk chopper, mower & $85-65$ & $6-10$ \\
\hline & Fertilizer & $90-60$ & $6-10$ \\
\hline
\end{tabular}

*Source: Hunt [1].

Field efficiency varies inversely with the machine theoretical capacity. One may intuitively think that a little time lost with a big machine implies heavy waste in potential production than a similar time waste with a small machine. Field capacity of a machine/implement also depends on the working speed. Thus, there may be a drop in the field efficiency if the machine/implement working speed is increased. An increase in travel speeds will decrease the productive working time needed.

However, when the time losses remain effectively the same, there will be drop in the field efficiency of the machine. Such a result according to [1], suggests that as much as there is a speed consideration, it is not good management to attempt to reduce field efficiency; therefore, it is not good operation to use slow speeds to achieve high field efficiency. Since high field capacity and/or material capacity can possibly be achieved with fast working speeds, an experienced operator should assess the soil and crop conditions and thus operate with high speed while maintaining the best quality of operation. 
In field operation speeds may be influenced by such factors as: machine overloading, poor steering operation, careful operation to avoid loss of functional and structural damage to the machine owing to rough ground surface and being prudent in handling materials. Machine overloading may have the greatest influence on the efficiency of the machine and may lead to failure/breakdown; while material handling has least effect on the efficiency of machine unless the machine is not in good working condition.

Values of machine capacities are applied in scheduling field operations, its power units and labour as well as determining machine operating costs. According to [4], different machines have different field efficiencies, though depending on the system of operations, soil type/ conditions and the system of management. Yohanna [22] and Yohanna [23] studied the field efficiency of some selected farm machinery in Nasarawa and Plateau states of Nigeria, but due to variation in agro-ecological areas and/or soil conditions according to [17], data obtained in the studies cannot guide farmers effectively in South-East Nigeria in selecting appropriate machinery that will suit their soil condition. Tables 2 presents the field efficiency of some tractor hitched implements in Nasarawa and Plateau State.

Table 2. Field efficiency of some selected farm machinery in Nasarawa and Plateau States, Nigeria.

\begin{tabular}{cc} 
in Nasarawa and Plateau States, Nigeria. \\
\hline Implements & Field efficiency (\%) \\
\hline Disc plough & 68 \\
Tandem harrow & 57 \\
Ridger & 56 \\
Combine seed drill & 56 \\
Boom sprayer & 60 \\
Combine harvester & 48 \\
\hline
\end{tabular}

Source: Yohanna [23].

Oduma et. al [24] evaluated the performance characteristics of agricultural field machineries in south- east Nigeria (Table 3) and observed that the average performance efficiency of plough was $87.11 \%$, while harrow, ridger, rotovator and planter recorded average field efficiencies of $86.32 \%, 86.78 \%, 87.14 \%$ and $86.81 \%$, respectively. However, the highest field efficiency for all the implements was obtained on sandy-clay soil with overall average efficiency of $87.35 \%$; followed by clay-loam that gave average efficiency of $86.53 \%$ and least was $86.21 \%$ obtained on loamy sandy soil. The authors noted that it could be due to low aggregation stability, high moisture content and low decomposed organic matter found in sandy-clay than other soil type as also observed by [25]. This is in agreement with the observations of [26] that soil type and condition are cardinal factors affecting field performance of farm tractors through their effect on the hitched implements and tractor traction force. It also confirms the findings of Smith [27] who posited that the performance of plough varies considerably according to the soil type. Despite the detailed time study made by these authors, they could not cover all the farm machinery used in farm operation in the South- east region of Nigeria. Their studies mostly focused on tillage and planting implements. 
Table 3. Field efficiency of some selected farm machinery in South-East Nigeria*

\begin{tabular}{cccccc}
\hline \multirow{2}{*}{$\begin{array}{c}\text { Soil textural } \\
\text { class }\end{array}$} & \multicolumn{5}{c}{ Implement performances $(f i e l d$ Efficiency, \%) } \\
\cline { 2 - 6 } & Plough & Harrow & Ridger & Rotovator & Planter \\
\hline Clay-loam & 87.41 & 82.06 & 84.41 & 87.13 & 86.18 \\
Clay-loam & 86.48 & 87.75 & 87.33 & 88.23 & 88.30 \\
Loamy-sandy & 87.47 & 85.83 & 87.51 & 84.91 & 85.31 \\
Sandy-clay & 85.12 & 86.85 & 86.64 & 87.78 & 86.35 \\
Sandy-clay & 88.07 & 89.12 & 88.03 & 87.64 & 87.92 \\
Average & 87.11 & 86.32 & 86.78 & 87.14 & 86.81 \\
\hline
\end{tabular}

*Source: Oduma et al. [24].

Performance efficiencies of chisel and disc ploughs and their impact on some physical properties of soil in Sudan was studied. Results of the study revealed that disc plough had field efficiency of $79.39 \%$ with average fuel consumption rate of 10.6 1/ha while the chisel plough recorded field efficiency of 73.4 1/ha and average fuel consumption rate of $13.47 \mathrm{l} / \mathrm{ha}$. However, their study centered on the plough tested on one soil type, other tillage implements and their power requirements were not considered; thereafter, they recommended that more investigations are needed to verify the impact of the ploughs under study on the physical properties of different types of soils in the area.

Sale et al. [7] evaluated the performance of some selected tillage implements in Samaru, Zaria. The study only considered one soil type/ textural class; and because of variations among soil types in an ecological area, results of such study cannot provide enough information that may guide farmers in selecting machines for their agricultural field operations. Saeed [28] investigated the performance efficiency of tractor - hitched tillage tools in clay soil in Urmia, Iran. This study was also based on only one soil type and because of the same reason, the results may not guide farmers properly in machine selection to be used in other soil types; furthermore, Iran and South-east Nigeria may not have the same soil type with same properties/conditions; there must be differences; in which case, farmers in Nigeria may not use data from such study area to select their farm machinery.

Olatunji [29] evaluated disc plough performance on sandy- loam soil at different moisture levels in Ilorin. Dimensional analysis approach was used to develop model expressions relating the cutting depth, disc plough weight and draught force on sandyloam soil. Despite the detailed study, did not consider the energy requirements of the implement for operation; and the study was conducted on only one soil type with only one tillage implement. These may not be enough to guide machine users in implement selection because of variations in soil type and conditions as emphasized earlier.

Finally, because of these variations that exist in the ecological soil types/conditions, [17] pointed out that performance data of field efficiencies under different soil conditions are very necessary for tractor and implement selection as these were essential parameters for measuring and evaluating performances of farm implements. Such data are not provided to agriculturists or farmers in Nigeria (by implement manufacturers) especially in the local areas to aid the farmers or users of the machines evaluate and possibly make suitable selections of the equipment before purchase. 


\section{Tractor Capacities}

In selecting reasonable field efficiency for a tillage operation, it is necessary to consider the effectiveness of the prime mover (tractor) in converting engine power to drawbar power. Nothing may be done to minimize power losses from the engine to the axle. Adequate maintenance operation may increase the efficiency of converting fuel energy into axle power but little or nothing can also be done to minimize energy losses. However, when considering losses from the farm tractor axle to the drawbar, energy is usually lost in order to create traction force applied to the tool which causes the implements to move through the soil [30]. This energy loss depends on the type and weight of the tractor, field conditions, and the load being pulled [31].

It is essential to know that drawbar force or power is the product of pull force and speed; where an infinite number of pull force and operation speed may be used to achieve the same power. Wheel tractors are aimed to work at higher operational speeds (higher than $8.0 \mathrm{~km} / \mathrm{h}$ ) and with lower drawbar forces. If low forward speeds (under 5.5 $\mathrm{km} / \mathrm{h}$ ) and large pull forces are to be constantly used, track layers should be considered. Table 5 shows the typical farm tractor efficiencies. The tractors recorded the same crankshaft and PTO powers of $100 \%$ and $85 \%$, respectively with maximum drawbar powers varying from 50 to $75 \%$.

Table 5. Typical tractor efficiencies

\begin{tabular}{ccccc}
\hline Tractor type & $\begin{array}{c}\text { Rated crankshaft } \\
\text { power }(\%)\end{array}$ & PTO power (\%) & $\begin{array}{c}\text { Drawbar power } \\
\text { (maximum), \% }\end{array}$ & $\begin{array}{c}\text { Drawbar power } \\
\text { (normal), } \%\end{array}$ \\
\hline $2 W D$ & 100 & 85 & 50 & $40-45$ \\
$F W A$ & 100 & 85 & 55 & $45-50$ \\
$4 W D$ & 100 & 85 & 60 & $50-55$ \\
Track & 100 & 85 & 75 & $65-70$ \\
\hline Note: PTO and Drawbar power are given as a percentage of the rated crankshaft power. Source:
\end{tabular}
William [31].

\section{INSTRUMENTATION AND EVALUATION}

In order to obtain data on the performance of agricultural field machinery, parameters such as the soil physical properties/conditions that affect machine performances, machine operational speed, productive time, effective width of operation, depth of cut and mass of material handled have to be determined. Some custom designed and/or specially developed instruments/equipment are used by various researchers to determine the soil physical properties. Thereafter, the performance indicators such as the field efficiency (a major indicator for machine selection), effective field capacity, theoretical field capacity, material capacity, and power and energy requirements are evaluated.

The machine speed can be selected or determined by noting the working or operation distance of the machine and time taken to cover such distance and evaluated using Equation (1) [6]:

$$
\mathrm{S}_{\mathrm{w}}=\frac{D w}{T t}
$$

Where: $\mathrm{S}_{\mathrm{w}}=$ Working speed, $\mathrm{kmh}^{-1} ; \mathrm{D}_{\mathrm{w}}=$ Working distance, $\mathrm{km} ; \mathrm{T}_{\mathrm{t}}=$ Total working time, (h) 
The productive time used in the operation is evaluated as expressed in Equation (2):

$$
\mathrm{T}_{\mathrm{e}}=\mathrm{T}_{\mathrm{t}}-\mathrm{T}_{\mathrm{d}}
$$

Where: $\mathrm{T}_{\mathrm{e}}=$ productive time, $\mathrm{hr} ; \mathrm{T}_{\mathrm{t}}=$ Total time spent on entire row length operation, $\mathrm{hr}$; $\mathrm{T}_{\mathrm{d}}=$ Delay (idle) time, $\mathrm{hr}$.

The delay or idle time includes, time for refilling fuel tank, time for repair of breakdown/adjustments, turning time and any other idle moment observed during operation except operators personal time.

The effective width of operation can be measured using measuring tape and the depth of cut can be selected or measured using wooden meter rule [1]. A weighing scale with accuracy of $0.1 \mathrm{~kg}$ and capacity of $520 \mathrm{~kg}$ is used to measure the mass of materials handled.

\section{Evaluation of Performance Indicators of Agricultural Field Machinery}

The various performance indicators considered in machine selection include: machine field efficiency, time efficiency, theoretical field capacity, effective field capacity, material capacity, energy consumption rate and power requirements of the machine. These indicators are essential factors for assessing the machine capacities and for adopting necessary management policies. They are used to ascertain how effective a machine would carry out its function and ensure timeliness of operation [19].

\section{Time efficiency}

Time efficiency is a percentage reporting the ratio of the time a machine is effectively operating to the total time the machine is committed to the operation [1] After determining the productive and the total time for each operation, the time efficiency can be obtained from Equation (3), according to [1]:

$$
\text { Time efficiency }=\frac{\text { Effective operating time }}{\text { total time of operation }}
$$

\section{Field efficiency} $[5]:$

The field efficiency is determined from the Equation (4) suggested by Kepner et al

$$
\varepsilon=\frac{100 T e}{T t}
$$

Where: $\varepsilon=$ field efficiency, $\% ; \mathrm{T}_{\mathrm{e}}=$ actual working (productive) time, $(\mathrm{h}) ; \mathrm{T}_{\mathrm{t}}=$ total working time $=\left(\mathrm{T}_{\mathrm{e}}+\mathrm{T}_{\mathrm{d}}\right)$, hr; $\mathrm{T}_{\mathrm{d}}=$ delay or idle time.

\section{Effective field capacity}

The effective field capacity is determined by noting the speed of operation, implements working width and the field efficiency of the machine; and then evaluated from Equation (5) suggested by Hunt [1]: 


$$
\mathrm{Ce}=\frac{\text { swe }}{c}
$$

Where: $\mathrm{Ce}=$ effective field capacity, ha/hr; $\mathrm{S}=$ speed, $\mathrm{km} / \mathrm{hr}[\mathrm{mi} / \mathrm{hr}] ; \mathrm{W}=$ rated width of implement, $\mathrm{m} ; \mathrm{e}=$ field efficiency as a decimal; $\mathrm{c}=$ constant, 10 .

Alternatively, the effective field capacity can be evaluated from Equation (6) as proposed by Kepner (1982):

$$
\mathrm{C} e=\frac{W S}{1000} \varepsilon
$$

Where: $\mathrm{w}=$ effective working width of machine, $\mathrm{m} ; \mathrm{S}=$ operation speed, $\mathrm{km} / \mathrm{h}^{-1}$; $\varepsilon=$ field efficiency, $\% ; \mathrm{C} e=$ effective field capacity, ha/h.

\section{Theoretical field capacity}

The theoretical field capacity can be determined by rearranging the expression suggested by [15] for field efficiency as given by Equations (7) and (8):

By rearrangement,

$$
\varepsilon=\frac{c e}{c t}
$$

$$
C_{t}=\frac{c e}{\varepsilon}
$$

Where: $C_{t}=$ theoretical field capacity, ha/hr; $C e=$ effective field capacity, ha/hr; $\varepsilon=$ field efficiency, decimal. [21]:

Alternatively, the theoretical field capacity can be evaluated using Equation (9),

$$
\mathrm{TFC}=\mathrm{W}_{\mathrm{t}} * \mathrm{~V}_{\mathrm{t}} * \mathrm{~K}
$$

Where: TFC $=$ theoretical field capacity, ha/hr; $\mathrm{W}_{\mathrm{t}}=$ theoretical operation width, $\mathrm{m} ; \mathrm{V}_{\mathrm{t}}=$ theoretical operation speed, $\mathrm{km} / \mathrm{h}^{-1} ; \mathrm{K}=$ constant $=0.1$.

Or by using Equation (10) suggested by Onwualu et al [2]:

$$
\mathrm{C}_{\mathrm{t}}=\mathrm{SW}
$$

Where: $\mathrm{C}_{\mathrm{t}}=$ theoretical field capacity, ha/h; $\mathrm{S}=$ speed of operation of machine, $\mathrm{km} / \mathrm{hr}$; $\mathrm{W}=$ effective width of operation of machine, $\mathrm{m}$.

\section{Material capacity}

The machine material capacity is determined by noting the speed of operation, implement working width, the field efficiency of the machine and the weight of soil scooped (for tillage implements), but for the planter, the quantity/weight of seeds loaded in the hopper; and for harvester the weight or quantity of seed/crop handled in a given time is obtained from the Equation (11) [1]: 


$$
\mathrm{M}=\frac{\text { Swey }}{c}
$$

Where: $\mathrm{M}=$ material capacity, $\mathrm{km} / \mathrm{h}^{-1} 1 ; \mathrm{y}=$ yield $/$ mass of material handled, $\mathrm{kg} / \mathrm{m}^{2} ; \mathrm{s}=$ implement/machine speed, $\mathrm{km} / \mathrm{hr} ; \mathrm{w}=$ implement working width, $\mathrm{cm}$; e = implement field efficiency, $\% ; \mathrm{c}=$ constant $=10$.

\section{Power requirements for tillage implements}

Measurement of draft: Draft is the power, in relation to pull-type or mounted implements, actually required to pull or move the implement at uniform speed. Draft is calculated due to drawbar power using Equation (12) [1]:

$$
D=\frac{C \times D B P}{S}
$$

Where: $D=$ draft, $\mathrm{kN} ; C=$ constant $=3.6 ; D B P=$ drawbar power, $\mathrm{kW} ; S=$ travel speed, $\mathrm{km} / \mathrm{h}^{-1}$.

Drawbar: The drawbar power is estimated from Equation (13) suggested by [1] as:

$$
\text { Drawbar power }=\frac{\text { Total draft, } \mathrm{kN} \times \text { speed }, \mathrm{km}^{-1}}{3.6(\text { constant })}
$$

\section{Fuel consumption}

A graduated cylindrical container may be used to measure the amount of fuel required to refill the fuel tank of the tractor immediately after a given operation as used by [12]. This measurement will provide the quantity of fuel consumed during any operation. The fuel consumption rates can be calculated in liter/ha or liter/hr as expressed in Equations (14) and (15) and suggested by Alnahas [25]:

$$
\begin{aligned}
& \text { Rate of consumption }(\mathrm{l} / \mathrm{ha})=\frac{\text { Reading of cylinder, } \text { litres }}{\text { Area of land covered, } \text {, hacters }} \\
& \text { Rate of consumption }(1 / \mathrm{hr})=\frac{\text { Reading of cylinder, litres }}{\text { Time taken to coverthe land area,hours }}
\end{aligned}
$$

\section{CONCLUSION}

Physical characteristics/conditions of soil has great influence on the performance of agricultural machines especially tillage implements while crop type and field condition has effect on planting and harvesting machines. It is a good culture to know the type, condition/characteristics of soil/field before engaging machines for any operation. Furthermore, knowledge of performance characteristics, energy and power requirements of field machinery will help farmers, farm managers and users of farm machinery to make proper selection based on soil type/condition for their agricultural operations to avoid or minimize unnecessary breakdown/failures, mismatching of implements to prime movers, loss of energy, power and time during operation and to increase production and for better management of the machinery at reduced cost. 
Average performance efficiency of disc plough in South- east Nigeria was $87.11 \%$, while harrow, ridger, rotovator and planter were $86.32 \%, 86.78 \%, 87.14 \%$ and $86.81 \%$, respectively.

Most studies were focused on a few soil types with few field implements. It was also observed from the review that data obtained for performance of various field machinery vary from one region to another and from one soil type to the other. Most studies reviewed did not consider the energy and power requirements of the machinery in operation.

\section{Recommendations for Future Works}

Based on the above conclusion, the following recommendations are made for future studies:

i. Differences exist in soil/field conditions among different agro-ecological areas; it is therefore recommended that studies should be conducted in every agricultural zone/area to obtain data on machine/implement performances based on soil/field conditions which will guide farmers in selecting proper machines that would suit their areas for increased production.

ii. Studies should be conducted with all the agricultural field machinery and on all the dominant soils used in farm operation, if comprehensive performance data for machine selection is to be obtained in South-East Nigeria.

iii. Farmers, farm managers and users of farm machinery should strictly use the performance data of machines in selecting proper machines for their farm operations to avoid mismatching of implements, failure/breakdown and energy loss during operation.

\section{REFERENCES}

[1] Hunt, D. 2013. Farm power and machinery management. Tenth edition. Scientific International Congress on Agricultural Engineering, Agricultural Engineering, Dubli. 3: 1703-1709.

[2] Onwualu, A.P., Akubuo, C.O. and Ahaneku, I.E. 2006. Fundamentals of Engineering for Agriculture Immaculate Publications Limited. 2 Aku stree, Ogui New Layout, Enugu, Nigeria.

[3] Ojha, T. P. and Michael, A. M. 2012. Principles of Agricultural Engineering. Vol.1. Jain Brothers. New Delhi (sixth edition).

[4] Yohanna, J. K. and Ifem, J. L.C.2003. Performance evaluation of field efficiency of farm machinery in Nasarawa and plateau state. Proceeding of the Nigerian Institution of Agricultural Engineers. Pp 88-92.

[5] Kepner, R. A, Bainer, R and Barger, E. L. 1982. Principles of Farm Machinery, AVI Publishing Company Inc. Wester port.

[6] Oduma, O., Igwe, J E. and Ntunde, D. I. 2015. Performance evaluation of field efficiencies of some tractor drawn implement in Ebonyi State. International Journal of Engineering and Technology, 5(4): 45-50.

[7] Sale, S. N., Gwarzor, M. A., Felix, O. G and Idris, S. I. 2013. Performance evaluation of some selected tillage implements. Proceedings of the Nigerian Institution of Agricultural Engineers, 34:71-77. 
[8] Oluka, S.I. 1998. Cost Study of tractor and equipment hiring and management system. Technology and Research Journal, 2(1): 58 - 70.

[9] Whitney, J. K. 1998. Choosing and using Farm Machines. Longman Publishers (PLC).Ltd, Singapore.

[10] Braid, F. G and Gwarzo, M.A. 1985. Capacitive performance of selected tillage machinery used in irrigation land condition. Paper presented at the $8^{\text {th }}$ Annual Conference of the Nigeria Society of Agricultural Engineers, Owerri.

[11] Updhyaya, S. K., Williams, T. H., Kemble, L. J. and Collins, N. E. 1984. Energy requirements for chiseling in coastal plain soils. Transactions of the ASAE, 27(6):1643-1649.

[12] Udo, D.U. and Akubuo, C.O. 2000. Fuel consumption in tillage operations for sandy loam soil. Proceedings of the Nigerian Institution of Agricultural Engineers, 9: $74-83$.

[13] Bukhari, S. B and Balock, J. M. 1982. Fuel consumption of tillage implements. AMA Japan, 11(3):20-22.

[14] Collins, N. E. Williams, T.H and Kemble L.J. 1998. Energy requirements for grain production system ASAE Pub., 407- 411, Asia, Africa and Latin America 19(4):9-14.

[15] Gbadamosi,L. and Magaji, A. S. 2003. Field study on animal draft for farming in Zeguma village of Niger State. Proceeding of Nigerian Institution of Agricultural Engineers.

[16] Kual, R.N and Egbo, C. O. 1985. Introduction to Agricultural Mechanization, $1^{\text {st }}$ edition, published by Macmillan Publisher. Ltd., London and Basingstoke. Pp. 71-72.

[17] Anazodo, U.G.N. 1983. Survey and comparative analysis of farm machinery management system in Nigeria. Proceedings of the Nigerian Institution of Agricultural Engineers, 7:59-73.

[18] Oluka, S.I. 2000. Costs of tractor ownership under different management systems in Nigeria. Nigerian Journal of Technology, 19(1):15-28.

[19] Grisso, R. D., Jasa, P. J. and Rolofson, D.E. 2002. Analysis of traffic patterns and yield monitor data for field efficiency determination. American Society of Agricultural Engineers. 18(20):171-178.

[20] Von-Bargen, K. and Cunney, M. B. 1974. Activity ratio for farm machinery operations analysis. Transactions of the ASAE 17(2): 225-227.

[21] ASAE 1999. Agro-Processing Engineering, American Society of Agricultural Engineers. CIGR Handbook of Agricultural Engineering. St Joseph, Michigan. Vol. III.

[22] Yohanna, J. K. 1998. An investment into the level of farm machinery utilization in Nigeria. A case study of plateau state. Unpublished M.Eng. Thesis. Dept. of Agric. Engineering, University of Makurdi, Nigeria.

[23] Yohanna, J. K. 2001. Level of farm mechanization in Nasarawa and Plateau State of Nigeria. Proceedings of $2^{\text {nd }}$ international conference of Nigerian Institution of Agricultural Engineers, Enugu, 23:7 -78.

[24] Oduma O., Oluka, S. I. and Eze, P. C. 2018. Effect of soil physical properties on performance of agricultural field machinery in south eastern Nigeria. CIGR Journal, 20(1): 25-31. 
[25] Alnahas, S.A.M.E. 2003.Tillage Implements Performance and their Effects on Two Types of Soil in Khartoum Area. Unpublished Thesis submitted to the University of Khartoum in partial fulfillment for the requirement of the Degree of Master of Science in Agricultural Engineering.

[26] Belel, M. M. and Dahab, M. H. 1997. Effect of soil condition on a two - wheel drive tractor performance using three types of tillage implements. University of Khartoum Journal of Agricultural Sciences . No. 5(2):1-20.

[27] Smith, L. A. 1993. Energy requirements for related crop production implements. Soil Tillage Research, 25 (4):281-299.

[28] Saeed, R., Mohammad, A., Javad, J. 2015. Performance of tractor and tillage implements in clay soil. Journal of the Saudi Society of Agricultural Sciences. Accepted article for publication.

[29] Olatunji. O.M. 2011. Evaluation of plough disc performance on sandy loan soil at different soil moisture levels. Research Journal of Applied Sciences, Engineering and Technology 3(3): 179-184.

[30] Shebi, J.G., Oni, K.C. and Braide, F.G.1988. Comparative tractive performance of three tractors. Journal of Agricultural Mechanization in Asia, Africa and Latin America, 19 (2):25-29.

[31] William, E. 2015. Crop - Machinery Management. Lower State University Extension and Outreach. Dept. of Economics, 641-732-5574.

\title{
SELEKCIJA POLJOPRIVREDNE MEHANIZACIJE I POBOLJŠANJE POLJOPRIVREDNIH OPERACIJA U JUGOISTOČNOJ NIGERIJI: PREGLED
}

\author{
Okechukwu Oduma ${ }^{1}$, Sylvester I. Oluka ${ }^{2}$, Nnaemeka R. Nwakuba ${ }^{1}$, \\ and Dilibe I. Ntunde ${ }^{2}$ \\ ${ }^{I}$ Department of Agricultural and Bioresources Engineering, \\ Michael Okpara University of Agriculture, Umudike, Nigeria. \\ ${ }^{2}$ Department of Agricultural and Bioresources Engineering, \\ Enugu State University of Science and Technology, Enugu, Nigeria.
}

Sažetak: Prikazan je pregled odabrane primene i korišćenja poljoprivrednih mašina na terenu za poboljšanje rada farme u jugoistočnoj Nigeriji. Pravilnim odabirom i upotrebom mehanizacije bez napora bi se povećala $\mathrm{i}$ optimizirala poljoprivredna proizvodnja minimiziranjem nepotrebnih kvarova, gubitaka energije i neusklađenosti uređaja sa pogonskim motorima. To se može postići samo uz pomoć podataka o performansama različitih mašina na terenu.

Pregled je pokazao da je prosečna efikasnost rada plugova u jugoistočnoj Nigeriji bila $87,11 \%$, dok su drljača, kultivator, rotofreza i sadilica imale efikasnost od $86,32 \%$, $86,78 \%, 87,14 \%$ i $86,81 \%$, respektivno.

Pregled je dalje utvrdio da je većina studija bila usredsređena na nekoliko tipova zemljišta sa nekoliko polja. Iz pregleda je takođe uočeno da podaci dobijeni za upotrebu različitih terenskih mašina variraju od jednog do drugog regiona i od jednog tipa do drugog tipa zemljišta, zbog variranja ekoloških uslova.

Većina razmatranih studija nije uzela u obzir zahteve mašina za energijom i snagom. 
Varijacije u agroekološkim tipovima i uslovima zemljišta zahtevaju studije različitih poljoprivrednih zona/područja kako bi se dobili podaci o karakteristikama rada poljoprivrednih mašina na terenu, koji bi usmerili poljoprivrednike i korisnike poljoprivredne mehanizacije u odabiru odgovarajućih mašina za njihovo određeno poljoprivredno zemljište. A tako određenim operacijama na terenu povećava se i njihova proizvodnja uz smanjene troškove.

Takođe su predstavljeni rezultati terenskih ispitivanja nekih mašina na farmama.

Predložene su perspektive za budući rad.

Ključne reči: Terenske mašine, performanse, selekcija, korišćenje, jugoistočna Nigerija.

Prijavljen:

Submitted:

Ispravljen:

Revised:

20.04.2019.

Prihvaćen:

Accepted:

25.05.2019

26.05.2019 